\title{
Progress in management of coastal ecosystems
}

\author{
J. Clark \\ The Conservation Foundation, 1717 Massachusetts Avenue, N. W.; \\ Washington, D. C. 20036, USA
}

\begin{abstract}
The process of coastal zone management in the United States has progressed to the point that it is now possible to embrace whole coastal ecosystems in management programs. The structural and dynamical features of the ecosystems have to be known before management can succeed. Furthermore, it is necessary to disaggregate the systems into subsystems. The following six subsystems have been used as the best compromise between scientific and administrative needs: the watershed terrain, the land drainage system, the coastal basin, the basin floor, the coastal waters, and the ocean. The Apalachicola National Estuarine Sanctuary in Florida is used as a case history of a managed ecosystem.
\end{abstract}

\section{INTRODUCTION}

Coastal ecosystem management has as its fundamental objective the concurrent and coordinated management of coastal lands and the waters of the adjacent sea. The management goal is to provide optimum benefits to the public from the resources of the coast. The key to success is simplicity, both in the expression of ecological purposes and in design of the management programs. Yet the need for simplicity is at odds with the inherent complexity of both ecological systems and political systems. This dilemma can best be resolved through enhanced empathy between science and management and through additional efforts by scientists to be relevant.

In this paper I examine the coastal ecosystem management framework within which marine biologists have been working recently in the United States. It is important first to recognize that the number of professionals technically equipped to deal with ecosystem management is quite limited. Such persons must be able to devise implementable programs, deal with conflicting interests, arrange compromises, and coordinate extremely varied activities. They are generalists, usually, who have a good grasp of biological, chemical, and physical sciences as well as the legal, administrative, and political arts.

Most scientists, by their very nature, are neither comfortable with the irrationality of politics nor patient with the tedium of administration and law (Clark, 1977). Therefore, the scientist usually is most comfortable in the role of simply providing information and leaving it to a special advocate to bring the ecosystem management program to fruition. Yet it is not always possible to cut the cake so cleanly. Those who have engaged in management will tell you how difficult it is to limit your input to scientific fact and how easy it is to get swept into and along with the whole management effort.

Among the environmental programs that were implemented during the United 
States ecology decade - 1968 to 1978 - were many that relate to coastal ecosystem management. For example: (1) the National Environmental Policy Act of 1969 (NEPA) which requires environmental impact statements on all major federal projects. (2) The Clean Water and Ocean Dumping Acts of 1972 which initiated strong controls on pollution of U.S. waters. (3) The national initiatives under the Clean Water Act and White House (Presidential) and Cabinet (Departmental) directives for protection of wetland habitats. (4) The Flood Disaster Protection Act of 1973 which, among other objectives, encourages conservation of coastal landforms (e. g. wetlands and sand dunes) that protect the coast. (5) The Coastal Zone Management Program (CZMP) authorized by the Federal Coastal Zone Management Act of 1972 (Public Law No. 92-583) which provides a mechanism for coordination of the variety of U.S. environmental programs that affect the coast.

The federal initiatives of the ecology decade were also supplemented by an extraordinary proliferation of environmental programs of state and local governments.

Of all these programs, coastal management at the ecosystem level in the United States is most strongly influenced by the CZMP. This program encourages each U.S. coastal state and territory to implement a specific management program in accordance with Federal guidelines and in cooperation with county and city governments. Its purposes include: resource and habitat conservation, improved public access to coastal waters, protection of life and property against storms, etc. It has the following major features: (1) It is voluntary. (2) Participating states receive annual federal grants for a planning phase of three to five years. (3) Once its plan is federally approved, each state receives annual grants for implementation of its program. (4) Federal actions are required to be consistent with and supportive of approved state programs. (5) Participating states are eligible for special purpose grants and loans for port improvement, fisheries development, compensation for damages caused by the oil industry, and establishment of protected areas called National Estuarine Sanctuaries (the subject of the following case study).

Although the coastal management program does not specifically require states to pursue conservation at the ecosystem level, its guidelines encourage comprehensiveness and thus do facilitate the ecosystem approach to conservation of coastal resources. At present (September, 1979) 30 states and territories are participating and 19 are operating approved programs.

The Federal Coastal Zone Management Program facilitates management at the ecosystem level primarily by fostering coordination among a variety of federal, state, and local government agencies. No single agency has sufficient authority to independently manage the lands and waters of an entire coastal ecosystem and each has its own narrow mission, special clientele, and bureaucratic resistance to change. The CZMP helps the advocate of ecosystem management to promote coordinated joint action among agencies because of its requirements for comprehensive planning and inter-governmental consistency.

It must be noted that the feasibility of management of entire ecosystems varies widely along the United States coastline, being affected greatly by population density, economics, culture, politics, and of course landform. It is clearly easier to control development in the narrow band of unbuildable land along a steep rocky shore than in the broad band of arable, buildable land of a low-lying coastal plain. 
In the interest of clarity some important terms are defined below.

Coastal: The land and water areas (marine and brackish, salinity $>$ than 0.5 percent) of the seacoast that are strongly influenced by each other; most extensive where there are broad low-lying coastal plains and large estuaries (Clark, 1977).

Ecosystem (coastal): An essentially complete ecological system consisting of a coastal water body coupled to the adjacent shorelands and watershed and the ocean.

Management: The organized social, political, and economic processes involved in coastal resources allocation and conservation.

Coastal basin: The submerged geologic structure of bays, estuaries, and other distinct coastal water bodies; specifically, the floor of a basin extending outwards and upwards to the low water mark periphery.

\section{ECOSYSTEM COMPONENTS}

As we have seen, coastal ecosystem management in the United States is normally approached as a process of coordinating diverse existing management authorities toward a common goal. Accordingly, for the practical purposes of management, the coastal ecosystem must be subdivided into components, each of which must be recognizable to various management authorities as bounding the areas of their separate jurisdictions. While it may seem to the ecologist quite impossible to divide an ecosystem in such a way as to serve both the political purposes of management authorities and the research purposes of science, in fact this has proved to be quite feasible in the United States as will be discussed below.

For any subject ecosystem, it is necessary to identify the major physical components and the dynamic processes at work as shown in Figure 1 where the estuarine and upland components of a Florida estuarine ecosystem are portrayed. The system should be divided into a logical arrangement of components - we have used six. Four of the six components of the generalized coastal ecosystem are evident in this particular case:

(1) The watershed: the upland terrain (or shorelands) that produces runoff water to the coastal basin (the "upland" of Fig. 1). (2) The land drainage system: the conduits that convey water to the coastal basin (canal, stream, subsurface flow, etc.) (the "upland water," "canal," etc. of Fig. 1). (3) The transitional area (edge-zone): lands regularly or sporadically flowed by sea water (marshes, swamps, flats, beaches, floodlands, etc.) ("mangrove" and "marsh" of Fig. 1). (4) The ocean: waters and oceanic forces that affect the coastal water basin but lie beyond its boundaries ("Gulf of Mexico" of Fig. 1). (5) The coastal waters: the brackish to saline waters that are found within the basin $(>0.5 \% \mathrm{~S})$ ("estuarine bays" of Fig. 1). A remaining ecosystem component that is not evident in Figure 1 but is implicit therein is: (6) The coastal basin: the basin structure including the floor and sides of the basin (a bay, lagoon, or sound) ("bay grasses" are basin bottom flora).

These six components, then, are the major physical subsystems of the coastal ecosystem that we have used for the purposes of management programs. Each individual subsystem is, of course, further divisible for either scientific or management purposes.

Before the management program can be formulated, science must identify the essential processes of the ecosystem, how they operate within each subsystem and how they are governed within and among subsystems. It is particularly important to identify 


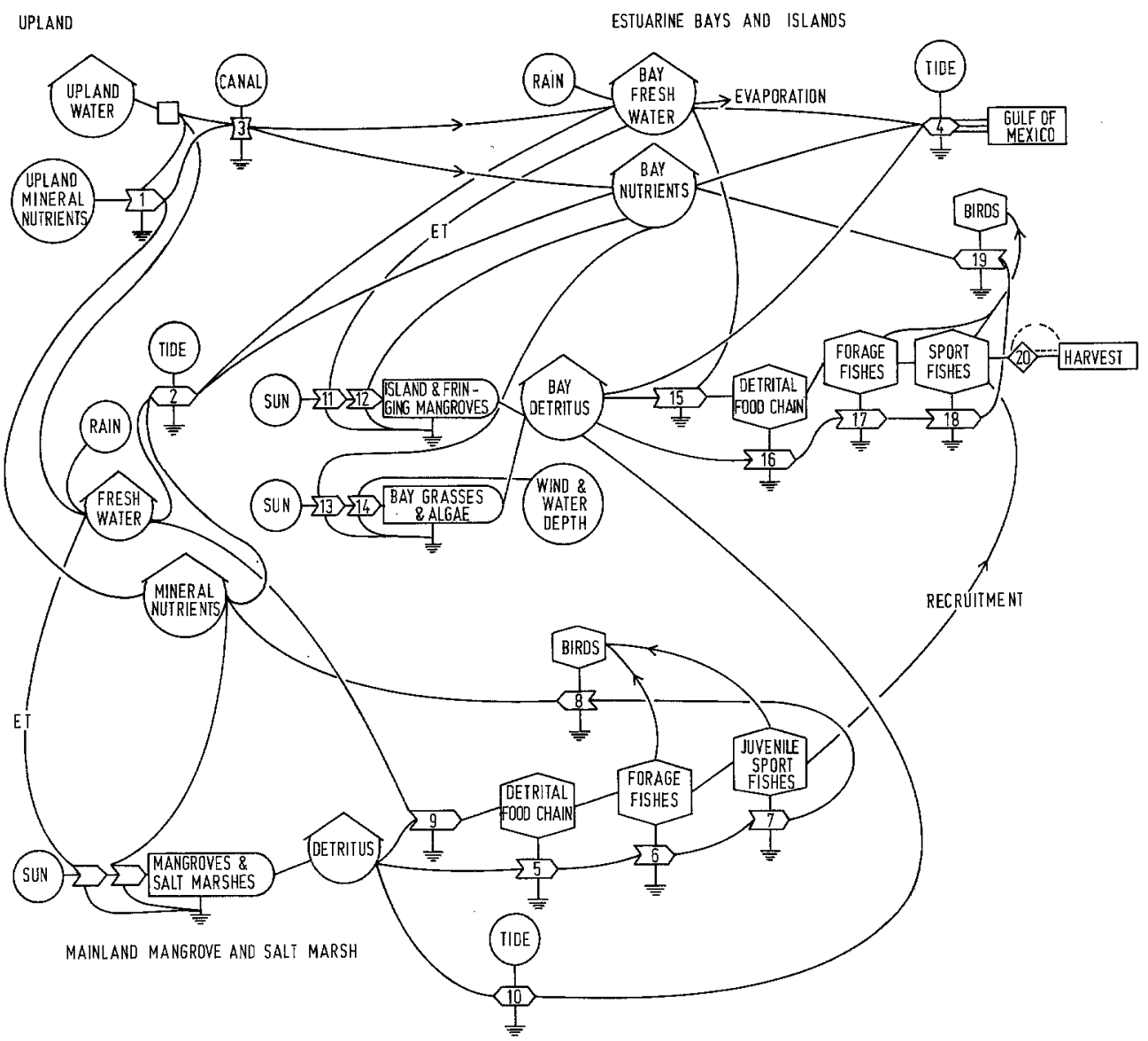

Fig. 1. Example of coastal ecosystem processes model (for a sub-tropical, mangrove-type system) that includes major system components (modified after Carter et al., 1973)

the $\mathrm{lim}$ iters (or limiting factors such as gases, mineral nutrients, and light) and the m od u 1 a t or s (or modulating factors, such as temperature, salinity, and water temperature) that influence the biological carrying capacity of the system because these must be dealt with directly by managers (Clark, 1977). There now exists within the common pool of scientific knowledge considerable information of this type that can form a general concept for application to all coastal ecosystems. But site-specific research is still essential for successful management. There is simply not a single prototype that can be applied to all cases. That is to say, while we can state the key parameters and draw generalized models, we cannot just use averaged biomass volumes and species compositions or standardized rates and coefficients in particular systems. An extraordinary variety of ecosystem types is to be found in the United States because of variations in geologic and climatic conditions.

Drawing the boundaries of the coastal ecosystem is an arbitrary and difficult job. Scientists and managers both may be puzzled by the process of jointly working out a 
common boundary delineation. However, as systems modelers know, much can be accomplished by transfer across model boundaries. Typically, the core of the ecosystem to be managed has been a bay, or other coastal water basin, and the brackish $(>0.5 \% \mathrm{~S})$ part of any tributaries that enter it, including: (1) the bay bottom, (2) the bay waters, and (3) the bay edges (transitional areas). The watershed, coastal drainage system, and ocean are often treated as external effects. Thus system modelers might draw their model boundary around the core area - the bay - and treat the upland and oceanic sources of water by transfer gates in the boundary. Of course, the transfer has to include the migrant and planktonic biota that cross the boundaries as well as the kinetic energy of tides and river flows and the dissolved and suspended inorganic content of the water. How the delineation of these components facilitates the management process is the subject of the next section of this paper.

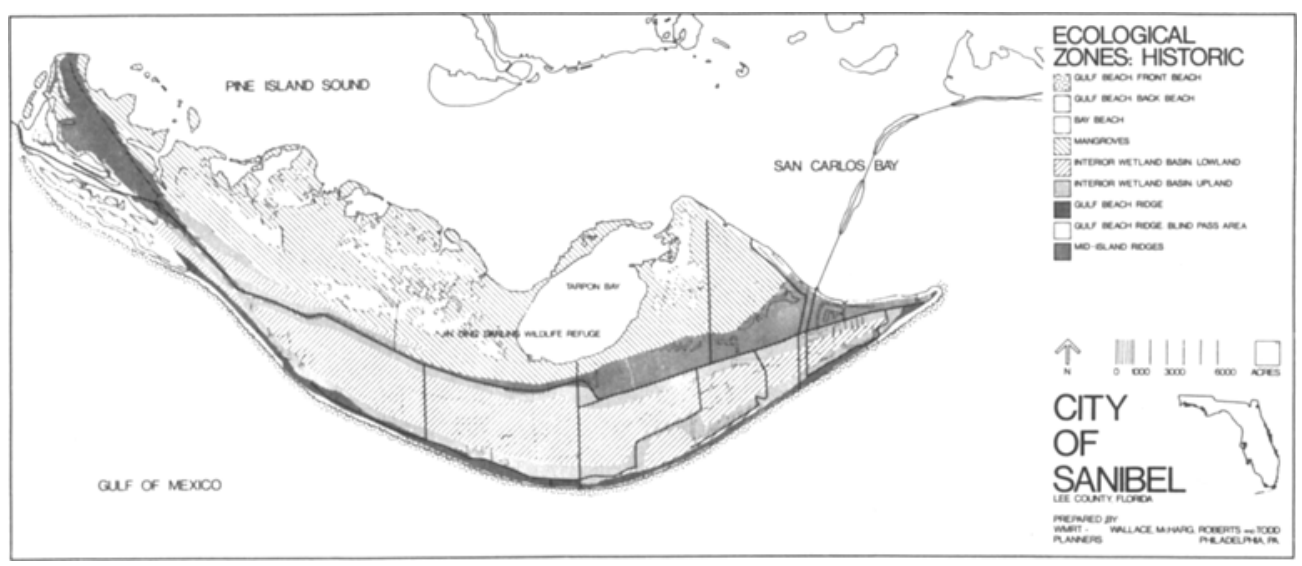

Fig. 2. Ecological zonation of Sanibel Island, Florida (after Clark, 1976)

It is clear that disaggregation of the ecosystem - component identification and characterization - is necessary. This will extend beyond definition of components to zonation within them. Ecological zonation is often the most valuable work the scientist can perform for the manager. Zonation of the physical environment gives the manager essential technical information in a form he can most easily understand and use to facilitate the management program. Three examples are given: The Mississippi Delta was zoned by Dr. Sherwood Gagliano and colleagues to benefit coastal management in the State of Louisiana. Sanibel Island, Florida (a very wet place which, while inhabited, lies totally within the transitional area component because the whole is subject to flooding if struck by a great hurricane), was zoned by a team of 15 scientists for the planning purposes of the City of Sanibel (Fig. 2). Corpus Christi Bay, was zoned by scientists of the Rice Institute to benefit the coastal zone management program of the State of Texas.

Another scientific contribution of importance is impact analysis. Because a major purpose of coastal ecosystem management is to minimize the impacts of human activities that adversely stress the ecosystem, one needs to identify the major potential effects that different human activities have on the ecosystem to be managed and to make provisions 
for these in the management program. For example, if large-scale harvest of forests in the watershed was not to be permitted, it would be wasteful to expend research resources on determining the effects of such cutting. However, if large-scale clearcutting was envisioned one would need to emphasize research on such effects as soil erosion, turbidity, siltation, water temperature, nutrient delivery, riparian habitat, and so forth. Environmental impact analysis, as this is called, is particularly difficult for coastal ecosystems because of the complexity of the impacts.

\section{THE MANAGEMENT CONTEXT}

Because, in its practical application, the management approach must be greatly simplified, a dilemma arises: on the one hand, the manager is uncomfortable with technical complexity and ambiguity; on the other hand, the scientist is uncomfortable with reductionist and unqualified certainty. The compromises that are made necessarily favor the manager's need for simplicity, and particularly of relating scientific knowledge to the political, legal, and administrative framework. A clear exposition of potential impacts, a proper arrangement of system boundaries, and appropriate zonation of subsystems can go a long way toward resolving the dilemma.

A brief description of management needs and the political, legal, and administrative process for each of the six general components follows to demonstrate how it has been possible to reconcile ecological and management aspects in the United States.

\section{Watersheds}

The watershed component is necessary to provide for control of disturbances of the terrain that drains into the coastal basin. When the watershed terrain is cleared for urbanization or agriculture it is not so capable of holding and modulating water flow, resulting in downstream flooding and unfavorable salinity oscillations. Nor is it so capable of retaining its soils or any toxic substances which have been applied.

The biological carrying capacity of many U.S. coastal basins has been greatly reduced by uncontrolled land use in the coastal terrain that drains into it. Accomplishing effective control over adverse land use in the coastal terrain has been politically difficult in the United States and remains a most troubling part of coastal ecosystem management because of the resistance of private land owners and the reluctance of local (sub-state) governments to relinquish control over land use to higher authority. The federal coastal management program has been rather unsuccessful in this regard. There is more hope of success through the Federal Clean Water Program run by the Federal Environmental Protection Agency (EPA) and operated largely by state and regional agencies. The program presently has some authority to control pollution from the land surface but EPA has been slow to exercise this authority. In the United States the federal government has traditionally avoided control of private land uses transferring most of this function to the states, who have in turn transferred most of it to sub-state government (cities and counties). Accordingly, most local governments have the right to exercise control over the terrain even though most of them do less with this authority than they could if politically motivated. However, under the influence of the ecology movement in the United States, many private landowners have voluntarily become far more responsible 
about controlling land uses that cause water pollution. Therefore, it is quite possible to develop workable watershed elements for coastal ecosystem management programs in many parts of the United States.

\section{The drainage system}

The rivers, canals, marshes, and other elements of the drainage subsystems that convey freshwater to the coast are an integral part of the hydrologic system and important to coastal ecosystems in many ways. The rivers provide pathways for migrant fauna, supply fresh water for dilution, facilitate circulation, and transport substances (both helpful and harmful). They also attract ships, industry, and dams. They are extremely important to coastal ecosystems where the shoreland is low, wide, backed by mountains, and cut by many rivers (e. g. the middle Atlantic Coast of the United States).

Rivers are largely controlled by the federal government through public works projects and permits for private developments. The U.S. Army Corps of Engineers controls river use, most importantly navigation and water resources development aspects; Interior and Agriculture Departments also have important roles in water development. Water is an important, often scarce, resource in the United States and its allocation and uses are dramatically and politically complex. The federal EPA controls river pollution, most often in partnership with individual state pollution control agencies. States generally allocate water supplies and some states (e. g. California) have active water resource programs (but these are subordinate to federal controls). The coordination of these authorities should not be so difficult because the Federal government has primary control, but the clientele for river development is so politically powerful that coastal ecosystem needs are often given a low priority.

\section{Transitional zone}

The transitional zone plays a key role in many ecosystems since it contains the floodlands, marshes, mangrove swamps, tideflats, beaches, and other elements subject to regular or sporadic tidal flooding. This zone has unique habitats, essential energy and material storage units, and important nutrient sources. The margin of the coast is also important in the protection of the land from the erosive forces of the sea.

The federal government has primary authority in the transitional zone. While the states can exercise secondary authority, the Corps of Engineers must approve any private development that affects wetlands, beaches, or tideflats. EPA and other federal agencies also must approve wetland projects. Federal and state governments have authority for flood management. Local governments exercise a variety of important secondary powers. Because the variety of authorities is great, coordination of them toward ecosystem management may be difficult. However, the agencies are experienced at cooperating on transition zone matters because much of the area, particularly that below mean high water, is typically in the public domain, the zone is narrow, and its character is obvious.

\section{The ocean}

The ocean lying beyond the boundaries of the coastal ecosystem has extremely important interactions with it. Waves, tides, and ocean currents provide kinetic energy 
and transport substances and biota to and away from the coastal basin. In confined coastal basins the ocean inlet is the transfer point through which all interaction occurs; therefore, the configuration of the inlet (often determined by engineers) is critical. The natural or artificial opening or closing of inlets as well as changes in their depth or width have most important effects upon coastal ecosystems (e. g. 60 to $70 \%$ of the coastal fish species of the U.S. Atlantic and Gulf Coasts use bays and estuaries for spawning, nursery, or feeding areas or have other significant dependencies).

The federal government has primary control over ocean affairs, including the immediate coast and the inlets. The Corps of Engineers is primarily responsible for physical and navigational aspects and the EPA for pollutional aspects. The National Marine Fisheries and U.S. Fish and Wildlife Service are advisors. State governments have a secondary role within the U.S. territorial sea (inside 3 miles).

\section{The coastal basin}

The coastal basin component (floor and sides that lie below the low water mark) has a special ecological role - it provides habitat and rich feeding areas for coastal fauna and is governed by a special assemblage of authorities. The condition of the basin floor influences not only its biological productivity and use by fauna but also the quality of water throughout the ecosystem (basins that are polluted with suspensible silts and chemicals usually have bad water quality). The basin floor also has vital ecological areas - features such as coral reefs, shellfish beds, and sea beds - that need particularly vigorous protection. The configuration of the coastal basin is also of great importance; channeling, deepening, causeway construction, or major bulkheading can greatly affect the carrying capacity of a bay or other coastal basin.

The federal government has primary control of the basin through its supreme authority over all navigation matters, but it often shares its powers with states. Sub-state governments are influential but have little direct power. EPA has control over pollutional aspects of dredging and spoil disposal. It is relatively simple to coordinate the various basin authorities for particular ecosystems, but it often is politically difficult to win a higher priority for ecological protection than for navigation projects.

\section{Coastal waters}

The water mass itself is identified as a separate component partly because of its natural distinctiveness and partly because of the alignment of authorities. Coastal water condition and its flow characteristics are strongly influenced by interactions with other subsystems. It is quite necessary to specify the requirements to be implemented in each of the other system components to provide adequate water condition and flow rates to satisfy needs of the basin. The most important in situ controls (within the basin) for the water subsystem apply to the discharge of pollutants. The most important external controls (outside the basin) are for water supply.

State agencies, under the guidance of the EPA, have the primary influence on pollution control (in some states the EPA has direct control). Sub-state governments have little influence. The U.S. Corps of Engineers has primary control on matters affecting water flow (however, see others mentioned under the coastal drainage system discus- 
sion). Coordination is relatively simple, the major problem being federal interagency conflicts.

\section{CASE STUDY - APALACHICOLA BAY (FLORIDA)}

The simplified case study that follows involves the development of a management proposal for a coastal ecosystem that lies in the northwest of Florida adjacent to the Gulf of Mexico, known as the Apalachicola Bay ecosystem. The proposal was developed under the National Estuarine Sanctuary Program of the Federal Coastal Zone Management Program. The Sanctuary Program provides federal grants and other assistance to states to manage particular ecosystems for research and educational purposes. The Sanctuary proposal for Apalachicola was successful because an extraordinarily energetic scientist, Robert J. Livingston, devoted his career to understanding the ecology of the Apalachicola system and because the fishing people of Apalachicola came to understand that only through an ecosystem approach to resource management could their livelihood and their way of life be sustained.

The coastal basin, Apalachicola Bay, is shallow with an average depth of about $3.5 \mathrm{~m}$; the bottom varies from coarse sand to fine mud. Oysters occur in concentrated reefs; submerged grass beds occupy 9,400 acres of the bay. Crabs, fish, and shrimp move between the bay and the ocean using the inlets as major pathways and all three use this bay as a major nursery area, as they do in so many estuaries of the Gulf of Mexico (for example, crabs travel hundreds of miles north along the Florida coast to spawn here) (U.S. Department of Commerce, 1979).

The watershed terrain is a mixed forest area, with pine plantations for pulpwood culture, some urban areas (including Atlanta, Georgia), and limited agriculture. The valley of the lower part (the Apalachicola River which runs for 107 miles through six Florida counties) is lightly developed.

The drainage system is extensive. The major conveyance of fresh water is the Apalachicola River which runs free from the Jim Woodruff dam and navigational locks at the Georgia border $170 \mathrm{~km}$ south to the Bay. Its mean annual flow is about 23,000 cfs. It is fed by the Flint and Chattahootchee Rivers which flow into a 37,500 acre impoundment behind the dam (Florida Division of State Planning, 1977). It carries the drainage from 19,500 square miles of watershed land $(17,000$ above the dam, 2,500 below). The river flows between natural berms that separate the channel form the floodlands during low river stage. It widens after it is joined by the Chipola River and becomes tidal and increasingly saline. It serves as a barge route from the Gulf to upriver industries in Alabama. Various sloughs lead back into the bottomland hardwood floodlands that are inundated each year. When they drain, great quantities of leaf detritus are carried downstream to enrich the bay. The flood zone is clearly delineated by alluvial soils.

The transition area surrounding the coastal basin varies from swamp to marsh (the marshes are widest on the inland edge of the bay) to sandy beaches with low dunes to earthen banks. Tidal amplitude is less than one meter. Flood risk is low except during hurricanes.

The water component includes the brackish part of the Apalachicola River (the lower $32 \mathrm{~km}$ ) and the bay proper. Salinity ranges from 0.5 to about $30.0 \%$. Industrial pollution is small, sewage is a factor in the vicinity of settlements. Circulation is largely wind driven. 
The ocean component interacts via three inlets (two natural and one man-made) through and around the outer boundary of barrier islands. Salinity varies from about 20.0 to $33.0 \%$. The continental shelf slopes vary gradually (about $2 \mathrm{~m} / \mathrm{km}$ ) and the coast is characterized as "medium energy."

In October 1978, the Conservation Foundation convened a workshop of 35 scientists representing a wide spectrum of disciplines to offer a plan for designation of the Apalachicola system as a National Estuarine Sanctuary. We had as a data base seven years of research by Dr. Livingston and several hundred colleagues and assistants. Ecological zonation of the system at macro levels and micro levels has been accomplished and a number of concept models have been constructed that couple the various subsystems together. Some models try to incorporate economic factors as well as to embrace the major ecologic aspects of the ecosystem. Simple hydro-biological numerical models are in operation and are being expanded by Livingston. New research initiatives are underway upriver and in the bay.

In three days of deliberations the workshop was able to provide the sponsoring federal and state agencies and some 50 other agencies and interest groups the following major advice (Clark \& Banta, 1979): (1) Regarding the basin: control dredging and spoil disposal to prevent impacts adverse to the sanctuary ecosystem and to gain any potential benefits from judicious placement of spoil. (2) Regarding the ocean: control inlet dredging or new structures to prevent adverse impacts on the sanctuary ecosystem through alterations of circulation, salinity, or predator ingress. (3) Regarding the water: control domestic waste to prevent the increase of human pathogen into the sanctuary ecosystem and control liquid waste effluent to prevent an increase in toxic, organic, or nutrient pollutants within the sanctuary ecosystem. (4) Regarding the watershed terrain: control alterations in the watershed of the sanctuary ecosystem to prevent an increase in non-point source pollutants from residential, agricultural, or forest cutting activities. (5) Regarding the transition area: exercise vigilant protection of the wetlands of the sanctuary ecosystem and the Apalachicola River. (6) Regarding the land drainage system: maintain the Apalachicola and tributaries in natural form and avoid engineering changes that would make it an artificial system.

Detailed scientific support for these minor points was given along with secondary advisories too numerous to discuss here. Most of our advice was incorporated into the subsequently proposed management proposal for the sanctuary (U.S. Department of Commerce, 1979).

The workshop succeeded in prescribing boundaries that would, in effect, give ecosystem status to the sanctuary. A core sanctuary area of land and water was recommended. The land part included 40,000 acres of existing publicly owned transitional and watershed land and an additional 12,000 acres to be purchased. The water area was to include 136,000 acres. To accomplish the necessary boundaries we tried to persuade the managers to include in the core of the sanctuary: (1) the Apalachicola River to the head of tide, (2) the Wimico tributary estuary, and (3) the transition areas along the private lands of the barrier islands. The sanctuary core thus corresponded with our idea of a minimum ecosystem model boundary.

It then remained to incorporate some control over the remaining three subsystems as external forces operating across the boundary of the core area. This was accomplished by persuading the managers to include, as a second management tier, further areas over 
which the sanctuary management would have purview. These were: (1) the Apalachicola River north to the Jim Woodruff dam, (2) the adjacent watershed, (3) the ocean inlets, and (4) certain critical direct drainages such as Tate's Hell Swamp (the site of forest cutting activity that released deleterious acid water to the Bay).

Thus the Apalachicola became the subject of a detailed proposal for an integrated coastal ecosystem management program. After making its rounds through the bureaucracy, public hearings, environmental impact analysis, and legal review for land purchase, it was approved and implemented in September 1979. Its California counterpart, the Elkhorn Slough ecosystem, was designated a national sanctuary at the same time. A Florida counterpart - Rookery Bay - was implemented in September 1977. A Hawaii counterpart - Waimanu Valley - was implemented in 1976. The successful establishment of protection programs for these four sanctuaries proves that coastal ecosystems can be managed as entire units.

\section{LITERATURE CITED}

Boynton, W. R., 1975. Energy basis of a coastal region: Franklin County and Apalachicola Bay, Florida. Ph. D. Diss., Univ. of Florida, Gainesville, Florida.

Carter, M. R., Burns, L. A., Cavinders, T. R., Duggan, K. R., Fore, P. L., Hicks, D. B., Revells, H. L. \& Schmidt, T. W., 1973. Ecosystems analysis of the big cypress swamp and estuary. U.S. Environmental Protection Agency, Washington, D.C.

Clark, J., 1976. The Sanibel report: Formulation of a comprehensive plan based on natural systems. The Conservation Foundation, Washington, D.C.

Clark, J., 1977. Coastal ecosystems management: A technical manual for the conservation of coastal zone resources. Wiley-Interscience, New York, $928 \mathrm{pp}$.

Clark, J., 1978. Natural science and coastal planning: The California experience. In: Protecting the golden shore. Lessons from the California Coastal Commissions. Ed. by Robert G. Healy. The Conservation Foundation, Washington, D.C.

Clark, J. \& Banta, J. S., 1979. Apalachicola symposium and workshops. A Report to the Florida Department of Environmental Regulation. The Conservation Foundation, Washington, D.C.

Florida Division of State Planning, 1977. The Apalachicola River and Bay System: A Florida resource. Bureau of Land and Water Management, Tallahassee, Florida (DSP-BLWM-5-77).

Gagliano, S. M. \& van Beek, J. L., 1975. An approach to multiuse management in the Mississippi delta system. In: Deltas, models for exploration. Ed. by M. L. Broussard. Houston Geological Society, Houston, Texas

Livingston, R. J., Sheridan, P. S., McLane, B. G., Graham Lewis III, F. \& Kobylinski, G. G., 1977. The biota of the Apalachicola Bay System: Functional relationships. - Fla mar. Res. Publs 26, 1-177.

National Science Foundation, 1973. Managing coastal lands. - Mosaic 4 (3), 26-32.

U.S. Department of Commerce and the State of Florida, 1979. Final environmental impact statement: Apalachicola River and Bay estuarine sanctuary. U.S. Dept. of Commerce, Office of Coastal Zone Management, Washington, D.C. 